\title{
MULTI-OBJECTIVE DISTRIBUTION FEEDER RECONFIGURATION BY CONSIDERING ENERGY NOT SUPPLIED WITH DISTRIBUTED GENERATION
}

\author{
Sankaramoorthy Muthubalaji, Veluchamy Malathi
}

Original scientific paper

Nowadays, the operational performance of the Distribution system can be improved by exchanging the functional links between the elements of the system, called reconfiguration. This paper aims at achieving such optimization through the reconfiguration of distribution systems taking into account various criteria. The newness of the method is in the fact that optimization is evaluated on active power distribution systems i.e by incorporating the distributed generators directly to the main distribution system. This paper presents a proficient method for solving the multi-objective reconfiguration of radial distribution systems with regard to distributed generators. The conformist distribution feeder reconfiguration (DFR) problem cannot meet the reliability requirements. The recommended approach considers reliability (Energy Not Supplied), voltage deviation and power loss problem simultaneously. By taking the reliability objective into account, the DFR problem becomes more complicated than before and it needs to be solved with a precise algorithm. Therefore this study utilizes Non Dominated Sorted Genetic Algorithm-II (NSGA-II) for DFR and Gravitational Search Algorithm (GSA) for DG placement is to find the optimal location and sizing of DGs which minimizes real power loss, Energy Not Supplied (ENS) and improves voltage profile of the network.

Keywords: distributed generation; Distribution Feeder Reconfiguration (DFR); Energy not Supplied (ENS); GSA; NSGA-II

\section{Rekonfiguracija multi-objektivnog distribucijskog napojnog voda s obzirom na neisporučenu energiju distribuirane proizvodnje}

Izvorni znanstveni članak

Danas se učinkovitost distribucijskog sustava može poboljšati zamjenom funkcionalnih poveznica između elemenata sustava, to jest rekonfiguracijom. Cilj je rada postići takvu optimizaciju rekonfiguracijom distribucijskog sustava uzimajući u obzir različite kriterije. Novina ove metode je u činjenici da se optimizacija procjenjuje na aktivnim sustavima raspodjele energije tj. ugrađivanjem distribuiranih generatora direktno u glavni distribucijski sustav. U radu se predstavlja napredna metoda za rješavanje multi-objektivne rekonfiguracije sustava radijalne distribucije u odnosu na distribuirane generatore. Konformistički promatran problem rekonfiguracije distribucijskog napojnog voda (DFR) ne može zadovoljiti zahtjevima za pouzdanošću. Preporučeni pristup uzima simultano u obzir problem pouzdanosti (neisporučena energija), devijacije u naponu i gubitka energije. Uzimajući u obzir pouzdanost, DFR problem postaje složeniji nego ranije i treba se riješiti preciznim algoritmom. Stoga se u ovom radu koristi Non Dominated Sorted Genetic Algorithm-II (NSGA-II) za DFR i Gravitational Search Algorithm (GSA) za optimalnu lokaciju i veličinu DG-ija jer se tako minimalizira stvarni gubitak energije, neisporučene energije (ENS) i poboljšava profil napona mreže.

Ključne riječi: distribuirana proizvodnja; neisporučena energija (ENS); GSA; NSGA-II; rekonfiguracija distribucijskog napojnog voda (DFR)

\section{Introduction}

In general, distribution system consists of a group of interconnected radial circuits. The efficient operation of distribution systems can only be achieved by modifying the open/closed status of sectionalizing-switches (normal closed) and tie switches (normal open) of the distribution systems. Reconfiguration is done especially for three purposes: 1 . for loss reduction, 2. for load balancing, and 3 . for service restoration [1].

Various methods have been proposed for solving the Distribution System Reconfiguration (DSR) problems. In [2], by optimal distribution system configuration, the lowest current is determined by the optimal power flow method. Other techniques like Quadratic programming [3] and network partitioning techniques [4], a heuristic nonlinear constructive method [5] are used in earlier stages. These methods find admirable solutions for the medium size systems and are not suitable for large systems [6]. In recent years, new heuristic optimization algorithms like Genetic Algorithm (GA) [7 $\div 11]$, Nondominated Sorting Genetic Algorithms (NSGA) [12], matroid theory [13], other meta-heuristics techniques like plant growth [14], Particle Swarm Optimization (PSO) [15], tabu search [16] and ant colony search [17, 18] have been proposed for DSR problem. They are aimed to deal with large system with fast execution time [19]. Recently DSR problem with distributed generation (DG) and capacitor allocation [20, 21] received much attention. Distributed Generation is a small-scale power generation that is directly connected to the distribution system or to the customer side of the meter. The benefits of DG are given in $[22,23]$. The power system performance can be enhanced to a greater extent only when the DGs are installed at proper location with proper capacity. Similar to DSR problem, several techniques and optimization algorithm, real coded genetic algorithm (RCGA) [24], Evolutionary Algorithm (EA) [25] have been proposed to optimize the location and sizing of distributed generation. Bacterial for aging algorithm (BFOA) [26] has been discussed for the reconfiguration problem. In [27] Harmony search algorithm was discussed for the DG placement. In $[29,30]$ NSGA is used to solve the three multi objective optimization problems and the result suggests that NSGA can be successfully used to find multiple Pareto optimal solutions the knowledge of which could be very useful to the designers and decision makers.

This paper proposes a method to reconfigure the distributed system with DG. A multi objective optimization algorithm, Gravitational Search Algorithm (GSA) is used to find the optimal location and sizing of DG, which minimizes real power loss, Energy Not Supplied (ENS) and improves voltage profile of the network. Non-Dominated Sorting Genetic Algorithm-II (NSGA-II) is used to find the switches to be opened in distributed system in order to minimize the real power 
loss and to improve voltage profile. GSA is a heuristic stochastic swarm-based search algorithm in the field of numerical optimization, based on the gravitational law and laws of motion. Like many other nature inspired algorithms, it needs refinements to maximize its performance in solving various types of problems. In addition to the problem encoding that sometimes can be a challenge, fine tuning its parameters plays a significant role balancing the search time versus solution quality. This algorithm is relatively recent and not heavily explored [30]. NSGA is a popular non-domination based genetic algorithm for multi-objective optimization. NSGA -II is based on the concept of Pareto dominance Incorporates elitism. It solves the optimization problems with reduced computational complexity and requires no knowledge of gradient information about the response surface. NSGA II is very resistant to finish with local optima and this special feature of NSGA II makes it more suitable for a wide variety of optimization problems in all fields of engineering. Due to these unique features, NSGA II becomes predominantly suitable for the problem proposed here. The proposed approaches have been tested on IEEE 33-bus radial distribution system and the results are presented. In this work, simulation is done using MATLAB. Even though there are several methods for the multi objective reconfiguration, the usage of Distributed Generation (DG) by considering reliability indices, particularly Energy Not supplied is rarely presented in the literature survey.

\section{DG Placement}

\subsection{Problem formulation}

Problem formulation is nothing but the formulation objective function with some constrained and decision variables. The objective function for DG placement is to find the optimal location and sizing of DGs which minimizes real power loss, Energy Not Supplied (ENS) and improves voltage profile of the network. It is mathematically formulated as

$$
\begin{aligned}
& \min f 1=\sum_{l=1}^{n l} P_{L}^{l} \\
& \min f 2=\sum_{i=1}^{n b} E N S_{i} \\
& \min f 3=\sum_{i=1}^{n b-g} V_{D_{i}}
\end{aligned}
$$

where,

$P_{L}^{l}$ - Real power loss in $1^{\text {st }}$ branch

$n l$ - No of branches in a network

$g$ - No of generator nodes in a network

$E N S_{i}$ - ENS of node $\mathrm{i}$ which is given by,

$$
E N S_{i}=P_{i} \sum_{i, j \in V, i \neq j}\left(U_{j, i}+U_{j, i}^{\prime}\right)
$$

where,

$V=\{1,2, \ldots . n b\}$,

$n b$ - No of nodes in a network

$P_{i}$ - Real power at bus I

$U_{j, i}$ and $U_{j, i}^{\prime}$ - Service unavailability associated with their construction time of all the branches connecting the node. $V_{D_{i}}$ - Voltage deviation of load bus $\mathrm{i}$, which is given by,
$V_{D_{i}}=\left(1-V_{i}\right)^{2}$

where,

$V_{i}$ - Voltage at bus ip.u.

\subsection{Real power and bus voltage constraints}

Real power limit of distribution feeders for the network should not be exceeded.

$P_{\mathrm{pq}} \leq P_{\mathrm{pq}}^{\max }$

where,

$P_{\mathrm{pq}}-$ Actual real power flow of the feeder between buses $\mathrm{p}$ and $\mathrm{q}$

$P_{\mathrm{pq}}^{\max }$ - Maximum thermal limit for the feeder between buses $\mathrm{p}$ and $\mathrm{q}$.

Voltage magnitude at each bus must lie within their permissible ranges and it is given by,

$V_{\mathrm{b}}^{\min } \leq V_{\mathrm{b}} \leq V_{\mathrm{b}}^{\max }$

where,

$V_{\mathrm{b}}$ - Voltage at bus b

$V_{\mathrm{b}}^{\max }$ - Maximum voltage at bus $\mathrm{b}$

$P_{\mathrm{b}}^{\min }$ - Minimum voltage at bus $\mathrm{b}$.

\subsection{DG rating constraints}

The ratings of $D G$ units must be constrained between its maximum and the minimum levels as given as follows,

$P_{D G, i}^{\min } \leq P_{D G, i} \leq P_{D G, i}^{\max }$

where,

$P_{D G, i}-D G$ capacity at bus $i$

$P_{D G, i}^{\max }$ - Maximum $D G$ capacity that can be placed at bus $i$ $P_{D G, i}^{\mathrm{min}}$ - Minimum $D G$ capacity that can be placed at bus $i$.

\subsection{Constraint for placing Number of $D G$}

$0 \leq D G_{n o} \leq 3$

$D G_{n o}$ - Number of $D G \mathrm{~s}$

\section{Optimization algorithm \\ 3.1 Gravitational search algorithm}

GSA is an optimization algorithm, which works based on law of gravity and law of motion. In GSA, a set of agents is called as objects and their masses are introduced by using law of gravity and law of motion in order to find the local optima in solution. The steps involved in the searching process are given as follows $[19,20]$ :

1) Consider a system with $N$ agents and the mass of the $i^{\text {th }}$ agent is given by,

$X_{i}=\left\{x_{i}^{1}, \ldots \ldots, x_{i}^{d}, \ldots \ldots x_{i}^{n}\right\} i=1,2, \ldots, N$ 
where, $x_{i}^{d}$ is the position of $i^{\text {th }}$ masses in the $d^{\text {th }}$ dimension and $\mathrm{n}$ is the total number of agents.

2) For all the agents fitness value is calculated. Among the fitness values, the best and the worst fitness are found out using

$\operatorname{best}(t)=\min f i t_{i}(t)$

$\operatorname{worst}(t)=\max f_{i t}(t)$

where

$f i t_{i}(t)$ is the fitness value of the $i^{\text {th }}$ agent at time $t$.

3) The gravitational constant $G(t)$ at time $t$ is calculated using the following function by having the initial value $G_{0}$,

$G(t)=G_{0} e^{-\propto \frac{t}{T}}$

4) Updation of mass of each agent is done by

$$
\begin{aligned}
& m_{i}(t)=\frac{\text { fit }_{i}(t)-\operatorname{worst}(t)}{\operatorname{best}(t)-\operatorname{worst}(t)} \\
& M_{i}(t)=\frac{m_{i}(t)}{\sum_{k=1}^{N} m_{k}(t)}
\end{aligned}
$$

5) Based on the law of gravity, the force acting on the $i^{\text {th }}$ mass is calculated as

$F_{i}^{d}(t)=\sum_{j=k b e s t, j \neq 1}^{N} \operatorname{rand}_{j} G(t) \frac{M_{j}(t) \cdot M_{i}(t)}{\left\|X_{i}(t), X_{j}(t)\right\|_{2}+\varepsilon}\left(x_{j}^{d}(t)-\right.$

$\left.x_{i}^{d}(t)\right)$

where

kbest is the set of first $k$ agents with best fitness value and biggest mass

rand $_{j}$ - Random number between 0 and 1

$M_{i}(t)$ and $M_{j}(t)$ are the gravitational masses of the $i^{\text {th }}$ agent and the $j^{\text {th }}$ agent

$\left\|X_{i}(t), X_{j}(t)\right\|_{2}$ is the Euclidian distance between the $i^{\text {th }}$ agent and the $j$ th agent

$\varepsilon$ is the small constant.

6) Then the acceleration of an agent is calculated as

$a_{i}^{d}(t)=\frac{F_{i}^{d}(t)}{M_{i}(t)}$

7) Finally the velocity and the position of each agent will be updated as

$V_{i}^{d}(t+1)=\operatorname{rand}_{i} \times V_{i}^{d}(t)+a_{i}^{d}(t)$

$x_{i}^{d}(t+1)=x_{i}^{d}(t)+V_{i}^{d}(t+1)$

8) Execution stops when the stopping criterion is reached.

Table 1 GSA Parameter

\begin{tabular}{|l|c|}
\hline \multicolumn{1}{|c|}{ Parameter } & Value \\
\hline Population size & 30 \\
\hline$G_{0}$ & 100 \\
\hline$\alpha$ & 20 \\
\hline No of iterations (T) & 100 \\
\hline
\end{tabular}

The parameters for GSA used in this paper are given in Tab. 1.

In our problem the population was chosen as 30 , since in IEEE 33 bus system there are 30 (Bus 2 - Bus 32) possibilities to place the DG. Other parameters were chosen as constant value [31], in such a way to obtain the optimal value.

\section{Reconfiguration of distribution system 4.1 Problem formulation}

Reconfiguration of feeders in distribution system should be done such as to minimize the real power loss and to improve the voltage profile of the network. It can be mathematically written as

$\min f 1=\sum_{l=1}^{n l} P_{L}^{l}$

$\min f 2=\sum_{i=1}^{n b-g} V_{D_{i}}$

where

$P_{L}^{l}$ - Real power loss in a line $l$

$n l$ - No of branches in a network

$n b$ - No of nodes in a network

$g$ - No of generator nodes in a network

$V_{D_{i}}$ - Voltage deviation of load bus $i$.

It is given as,

$V_{D_{i}}=\left(1-V_{i}\right)^{2}$

where,

$V_{i} \quad$ - Voltage at bus i in p.u

\subsection{Real power and bus voltage constraints}

Real power limit of distribution feeders for the network should not be exceeded.

$P_{\mathrm{pq}} \leq P_{\mathrm{pq}}^{\max }$

where,

$P_{\mathrm{pq}}$ - Actual real power flow of the feeder between buses $\mathrm{p}$ and $\mathrm{q}$

$P_{\mathrm{pq}}^{\max }$ - Maximum thermal limit for the feeder between buses $\mathrm{p}$ and $\mathrm{q}$.

Voltage magnitude at each bus must lie within their permissible ranges and it is given by,

$V_{\mathrm{b}}^{\min } \leq V_{\mathrm{b}} \leq V_{\mathrm{b}}^{\max }$

where,

$V_{\mathrm{b}}$ - Voltage at bus b

$V_{\mathrm{b}}^{\text {max }}$ - Maximum voltage at bus $\mathrm{b}$

$P_{\mathrm{b}}^{\min } \quad$ - Minimum voltage at bus $\mathrm{b}$.

\subsection{Radiality constraints}

Under this constraint the radial structure of network should not be affected and all the nodes should be energized. 


\section{Optimization algorithm for reconfiguration}

\subsection{Non-Dominated Sorting Genetic Algorithm (NSGA)}

NSGA is a multi-objective optimization technique also known as Pareto optimization. It is an area of multiple criteria decision making, that is simultaneously optimizing the multiple objective. A solution is called non dominated Pareto optimal, if none of the objective functions can be improved in value without degrading some of the other objective values [32].

In NSGA-II, first the off spring population $Q_{t}$ (of size $N$ ) using the parent population $P_{t}$ (of size $N$ ) is created.The usual genetic operators such as single- point crossover and bit-wise mutation operators are used in this process. Next, to form an intermediate population $R_{t}$ of size $2 N$ the two population was combined. Thereafter, the fitness of each offspring in the $2 N$ population was evaluated using the multiple objective functions. At this stage, non-dominated sorting procedure over the $2 \mathrm{~N}$ population was carried out to rank and divide the individuals into different non-dominated fronts. Thereafter, the new parent population $P_{t}+1$ by choosing individuals of the non-dominated fronts was created, one at a time. The individuals of best ranked fronts first followed by the next-best and so on, till obtaining $N$ individuals. Since the intermediate population $R_{t}$ has a size of $2 N$, those fronts which could not be accommodated were discarded. In case there is space only for a part of a front in the new population, crowdeddistance operator was used to determine the individuals among those in the front that are from the least crowded regions. Such individuals were chosen so as to fill up the required number in the new population $P_{t}+1$.

Table 2 NSGA-II Parameters

\begin{tabular}{|l|c|}
\hline \multicolumn{1}{|c|}{ Parameter } & Value \\
\hline No of population & 20 \\
\hline No of generation & 200 \\
\hline Cross over probability & 0,9 \\
\hline Mutation probability $(1 / N-$ no of decision variables $)$ & 0,2 \\
\hline Crossover index & 20 \\
\hline Mutation index & 20 \\
\hline
\end{tabular}

The complete NSGA-II procedure is given below:

\section{BEGIN}

While generation count is not reached

\section{Begin Loop}

- Combine parent $P_{t}$ and offspring population

- $Q_{t}$ to obtain population $R_{t}$ of size $2 N$

- Perform Non-dominated Sort on $R_{t}$ and assign ranks to each Pareto front with fitness $F_{i}$.

- $\quad$ Starting from Pareto front with fitness $F_{1}$, add each Pareto-front $F_{i}$ to the new parent population $P_{t}+1$ until a complete front $\mathrm{Fi}$ cannot be included.

- $\quad$ From the current Pareto-front $F_{i}$, add individual members to new parent population $P_{t}+1$ until it reaches the size $N$.

- Apply selection, crossover and mutation to new parent population $P_{t}+1$ and obtain the new offspring population $Q_{t}+1$.

- Increment generation count.

- $\quad$ End Loop
END

The parameters for NSGA-II used in this paper are given in Tab. 2.

\section{Results and Discussions}

The enactments of suggested methods are tested on IEEE- 33 bus radial distribution system using MATLAB. The single line diagram of test system is shown in Figure 1. The test system comprises 33 buses, 32 sectionalizing switches and 5 tie line switches. In this network, sectionalizing switches which are normally closed are numbered from 1 to 32 and tie-switches which are normally opened are numbered from 33 to 37 . Simulation is carried by taking three cases into account such as Case 1: base case, Case 2: Test system without reconfiguration with multiple DG, Case 3: Reconfigured network with multiple DG.

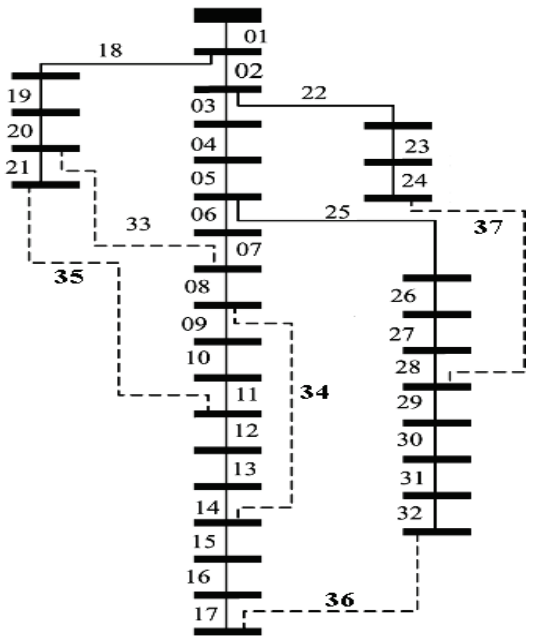

Figure 1 Single line diagram of IEEE 33 bus radial distribution System

\subsection{Case1: Base Case}

In this approach, forward and Backward Sweep Algorithm is used for load flow analysis since it is steadfast and gives accurate results for distribution system [28]. The load flow is performed on test system without connecting tie line Switches and without any DG., it resulted that real power loss, voltage deviation as 210,0594 and 0,1328 respectively. The Energy Not Supplied (ENS) was also obtained as $11,8406 \mathrm{kWh} / \mathrm{yr}$.

\subsection{Case 2: Test system without reconfiguration with multiple DG}

Gravitational Search Algorithm (GSA) used for the optimization of multiple DG location, DG ratings and the achieved results are shown in Tab. 3. The fitness curve obtained for multiple DG using GSA is shown in Fig. 2 when the two DGs are located at 32, 18 the real power loss is minimized to $166,4732 \mathrm{~kW}$. By adding one more DG, the power loss is again minimized to $156,3369 \mathrm{~kW}$ the voltage deviation also improved from 0,1328 to 0,0749 . When we are placing the multiple DGs at the optimized location as shown in Tab. 4. The ENS also gets reduced from $11,8406 \times 10^{4} \mathrm{kWh} / \mathrm{yr}$ to $3,3210 \times 104$ $\mathrm{kWh} / \mathrm{yr}$ 
Table3 Effects of single and multiple DGs

\begin{tabular}{|c|c|c|c|c|c|c|}
\hline S. No & Case & DG location & $\begin{array}{c}\text { DG size } \\
(\mathrm{kW})\end{array}$ & $\begin{array}{c}\text { Real power loss } \\
(\mathrm{kW})\end{array}$ & $\begin{array}{c}\text { Voltage } \\
\text { Deviation }\end{array}$ & $\begin{array}{c}\mathrm{ENS} \times 10^{4} \\
\mathrm{kWh} / \mathrm{yr}\end{array}$ \\
\hline 1 & Base case & - & - & 210,0594 & 0,1328 & 11,8406 \\
\hline 2 & With $1 \mathrm{DG}$ & {$[23]$} & {$[149,97]$} & 192,1160 & 0,1035 & 3,3842 \\
\hline 3 & With 2 DG & {$\left[\begin{array}{ll}32 & 18\end{array}\right]$} & {$\left[\begin{array}{ll}149,99 & 109,21\end{array}\right]$} & 166,4732 & 0,0857 & 3,3536 \\
\hline 4 & With 3 DG & {$\left[\begin{array}{lll}17 & 32 & 12\end{array}\right]$} & {$\left[\begin{array}{llll}124,34 & 139,99 & 132,40\end{array}\right.$} & 156,3369 & 0,0749 & 3,3210 \\
\hline
\end{tabular}

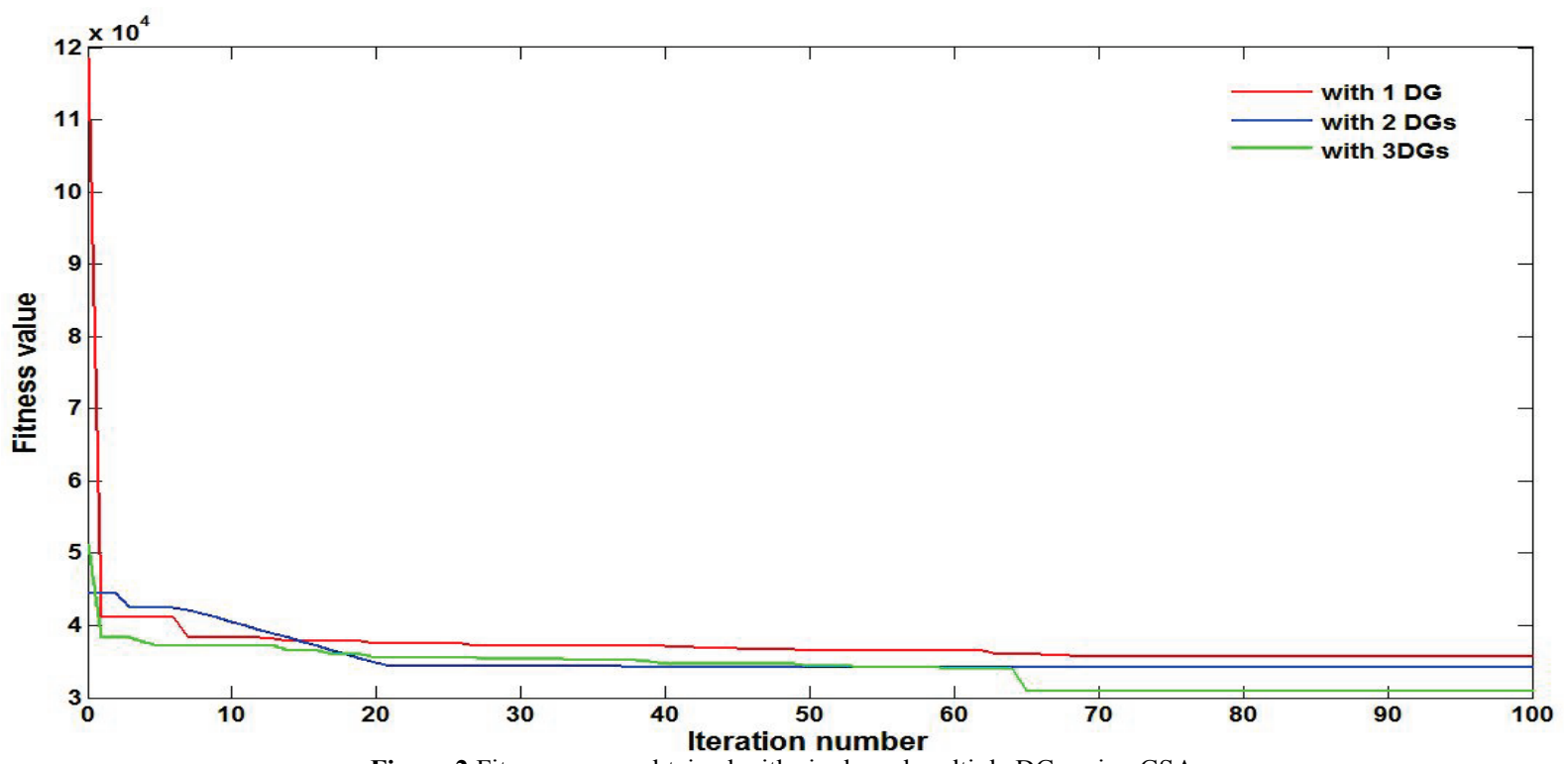

Figure 2 Fitness curves obtained with single and multiple DGs using GSA

Table 4 Reconfiguration results with single and multiple DGs using NSGA-II

\begin{tabular}{|c|c|c|c|c|c|}
\hline S. No & Case & Switches Opened & $\begin{array}{c}\text { Real power loss } \\
(\mathrm{kW})\end{array}$ & Voltage deviation \\
\hline 1 & With 1 DG & {$\left[\begin{array}{ll}713101728\end{array}\right]$} & 97,1218 & 0,0395 \\
\hline 2 & With 2 DG & {$\left[\begin{array}{lll}3312101522\end{array}\right]$} & 70,6359 & 3,3842 \\
\hline 3 & With 3 DG & {$\left[\begin{array}{lll}71411528\end{array}\right]$} & 58,9464 & 0,0273 \\
\hline
\end{tabular}

\subsection{Case 3: Reconfigured network with multiple DG}

In this case, reconfiguration is done using NSGA for the test system after installing DGs at their proper location. The effects of this reconfiguration on system with DGs are obtained and it is shown that both real power loss and voltage deviation get minimized more than those of other 2 cases, as shown in Tab. 4. The graph showing the voltage profile for all the three cases is shown in Fig. 3. From this figure it can be revealed that by having the NSGA based reconfigured network with DG, the voltage profile has been improved more. The Tab. 5 gives the comparison of results obtained for all three cases. The ENS was not affected by the reconfiguration since we have taken this as independent to the line configuration.

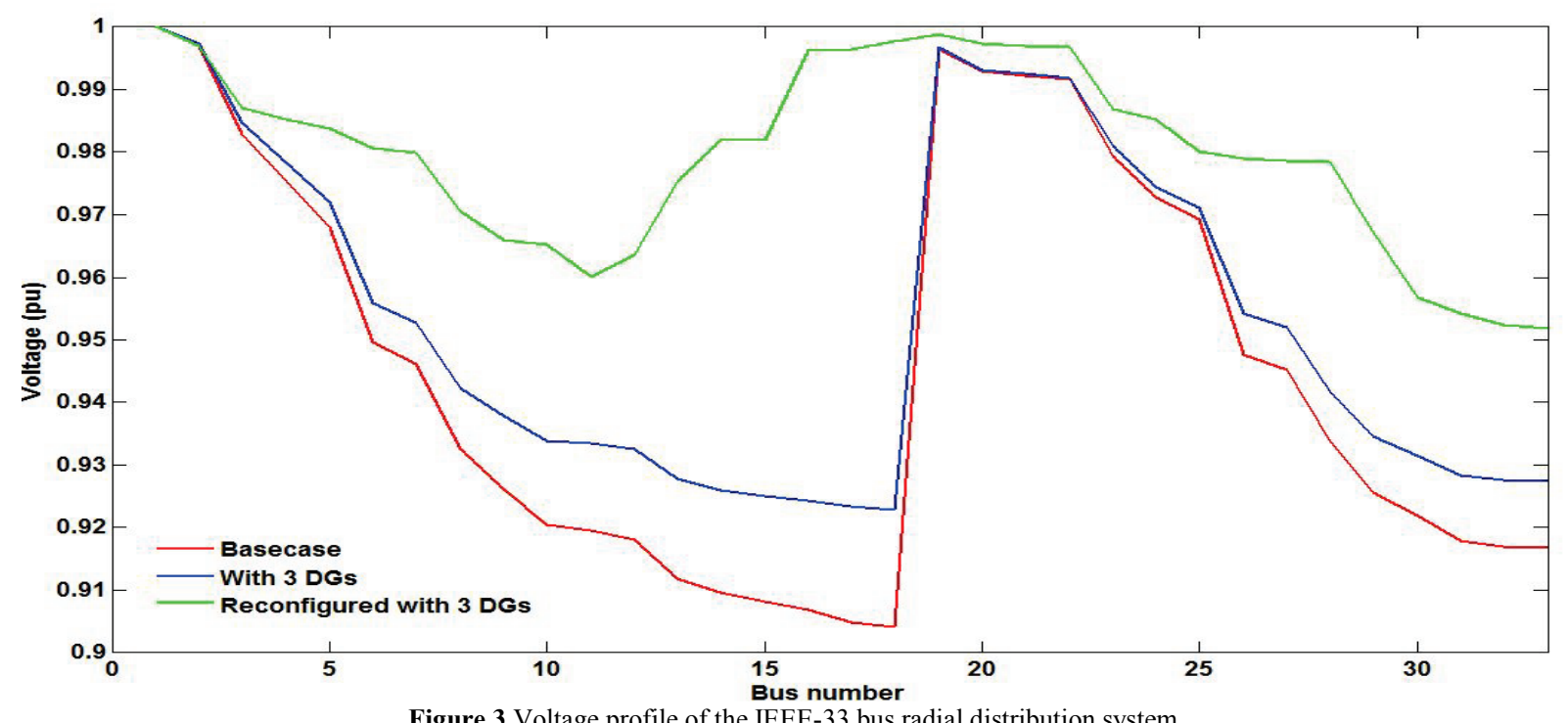

Figure 3 Voltage profile of the IEEE-33 bus radial distribution system 


\begin{tabular}{|c|c|c|c|c|c|c|c|}
\hline \multirow[b]{2}{*}{ S. No } & \multirow[b]{2}{*}{ No. of DGs } & \multicolumn{3}{|c|}{ Without reconfiguration } & \multicolumn{3}{|c|}{ With reconfiguration } \\
\hline & & $\begin{array}{l}\text { Real power } \\
\text { loss }(\mathrm{kW})\end{array}$ & $\begin{array}{c}\text { Voltage } \\
\text { deviation }\end{array}$ & $\mathrm{ENS} \times 10^{4} \mathrm{kWh} / \mathrm{yr}$ & $\begin{array}{l}\text { Real power loss } \\
(\mathrm{kW})\end{array}$ & $\begin{array}{c}\text { Voltage } \\
\text { deviation }\end{array}$ & $\begin{array}{c}\text { ENS } \times \\
10^{4} \mathrm{kWh} / \mathrm{yr}\end{array}$ \\
\hline 1 & 1 & 192,1160 & 0,1035 & 3,3842 & 97,1218 & 0,0395 & 3,3842 \\
\hline 2 & 2 & 166,4732 & 0,0857 & 3,3536 & 70,6359 & 0,0273 & 3,3536 \\
\hline 3 & 3 & 156,3369 & 0,0749 & 3,3210 & 58,9464 & 0,0211 & 3,3210 \\
\hline
\end{tabular}

\section{Conclusion}

Reconfiguration exemplifies one of the most important dealings which can improve the performance of a distribution system. An optimal reconfiguration of a power distribution system is not a new problem but is still a difficult one and nowadays has new challenges. Besides active power losses, the DG placement problem and reconfiguration problem is formulated as a non-linear optimization problem with the objective of loss minimization and voltage profile improvement by considering the Energy Not Supplied (ENS). The location and sizing of multiple DGs were optimized using Gravitation Search Algorithm (GSA). For reconfiguration, the optimal switches to be opened in distributed system were found using Non-Dominated Sorting Genetic Algorithm (NSGA). The criteria for optimization have been evaluated on active power distribution systems. The simulation studies on test systems have emphasized that the feeder reconfiguration problem can be more efficiently solved with NSGA than in the case of distributed generators connected directly to the main distribution system. This paper deals with an original genetic algorithm (based on NSGA-II) to solve the problem in a non-prohibitive execution time.

\section{References}

[1] Baran, M. E.; Wu, F. F. Network reconfiguration in distribution systems for loss reduction and load balancing. // IEEE Trans. Power Deliv. 4, 2(1989), pp. 1401-1407. DOI: 10.1109/61.25627

[2] Shirmohammadi, D.; Hong, H. W. Reconfiguration of electric distribution networks for resistive line losses. // IEEE Trans Power Delivery. 4, 2(1989), pp. 1401-14921498.

[3] Glamocamin, V. Optimal loss reduction of distribution networks. // IEEE Trans Power Syst. 5, 3(1990), pp. 774781. DOI: $10.1109 / 59.65905$

[4] Sarfi, R.; Salama, M.; Chikhani, Y. Distribution system reconfiguration for loss reduction: an algorithm based on network partitioning theory. // IEEE Trans Power Syst. 11, 1(1996), pp. 504-510. DOI: 10.1109/59.486140

[5] McDermott, T.; Drezga, I.; Broadwater, R. A heuristic nonlinear constructive method for distribution system reconfiguration. // IEEE Trans Power Syst. 14, 2(1999), pp. 478-483. DOI: $10.1109 / 59.761869$

[6] Carreno, E. M.; Romero, R.; Padilha-Feltrin, A. An efficient codification to solve distribution network reconfiguration for loss reduction problem. // IEEE Trans Power Syst. 23, 4(2008), pp. 1542-1551. DOl: 10.1109/TPWRS.2008.2002178

[7] Nara, K.; Shiose, A.; Kitagawa, M.; Ishibara, T. Implementation of genetic algorithm for distribution systems loss minimum reconfiguration. // IEEE Trans Power Syst. 7, 3(1992), pp. 1044-1051. DOI: 10.1109/59.207317

[8] Lin, W. M.; Cheng, F. S.; Say, M. T. Distribution feeder reconfiguration with refined genetic algorithm. // Gener
Trans Distrib. 147, 6(2000), pp. 349-354. DOI: 10.1049/ipgtd:20000715

[9] Zhu, J. Z. Optimal reconfiguration of electrical distribution network using the refined genetic algorithm. // Electr Power Syst Res. 62, (2002), pp. 37-42. DOI: 10.1016/S0378$7796(02) 00041-X$

[10] Mendoza, J.; Lopez, R.; Morales, D.; Lopez, E.; Dessante, P.; Moraga, R. Minimal loss reconfiguration using genetic algorithms with restricted population and addressed operators: real application. // IEEE Trans Power Syst. 21, 2(2006), pp. 948-954. DOI: 10.1109/TPWRS.2006.873124

[11] Gonzalez, A.; Echavarren, F. M.; Rouco, L.; Gomez, T.; Cabetas, J. Reconfiguration of large scale distribution networks for planning studies. // Int J Elect Power Energy Syst. 37, 1(2012), pp. 86-94. DOl: 10.1016/j.ijepes.2011.12.009

[12] Chandramohan, S.; Atturulu, N.; Kumudini, R. P.; Ventakesh, B. Operating cost minimization of a radial distribution system in a deregulated electricity market through reconfiguration using NSGA method. // Int J Electr Power Energy Syst. 32, 2(2010), pp. 126-132. DOI: 10.1016/j.ijepes.2009.06.023

[13] Enacheanu, B.; Raison, B.; Caire, R.; Devaux, O.; Bienia, W.; Hadjsaid, N. Radial network reconfiguration using genetic algorithm based on the matroid theory. // IEEE Trans Power Syst. 23, 1(2008), pp. 186-195. DOI: 10.1109/TPWRS.2007.913303

[14] Wang, C.; Zhong, H. Optimization of network configuration in large distribution system using plant growth simulation algorithm. // IEEE Trans Power Syst. 23, 1(2008), pp. 119-126. DOI: 10.1109/TPWRS.2007.913293

[15] Sivanagaraju, S.; Viswanatha, J.; Sangameswara, P. Discrete particle swarm optimization to network reconfiguration for loss reduction and load balancing. // Electr Power Compon Syst. 36, 5(2008), pp. 513-524. DOI: 10.1080/15325000701735389

[16] Abdelaziz, A. Y.; Mohammed, F. M.; Mekhamer, S.F.; Badr, M. A. L. Distribution system reconfiguration using a modified tabu search. // Electr Power Syst Res. 80, 8(2010), pp. 943-953. DOI: 10.1016/j.epsr.2010.01.001

[17] Su, C. T.; Chang, C. F.; Chiou, J. P. Distribution network reconfiguration for loss reduction by ant colony search algorithm. // Elect Power Syst Res. 75, 2-3(2005), pp. 190199. DOI: 10.1016/j.epsr.2005.03.002

[18] Abdelaziz, A. Y.; Osama, R. A.; El-Khodary, S. M. Reconfiguration of distribution systems for loss reduction using the hypercube ant colony optimization algorithm. // IET Gen Trans Dist. 6, 2(2012), pp. 176-187. DOI: 10.1049/iet-gtd.2011.0281

[19] Gomez, F.; Carneiro, S.; Pereira, J. L. R.; Vinagre, M.; Garcia, P.; Araujo, L. A new heuristic reconfiguration algorithm for large distribution systems. // IEEE Trans Power Syst. 20, 3(2005), pp. 1373-1378. DOI: 10.1109/TPWRS.2005.851937

[20] Lucia, C.; Borges, T.; Ferreira, V. Multistage expansion planning for active distribution networks under demand and distributed generation. // Int J Electr Power Energy Syst. 36, 1(2012), pp. 107-116. DOI: 10.1016/j.jiepes.2011.10.031

[21] Szuvovivski, I.; Fernandes, T. S. P.; Aoki, A. R. Simultaneous allocation of capacitors and voltage regulators at distribution networks using genetic algorithms 
and optimal power flow. // Int J Elect Power Energy Syst. 40, 1(2012), pp. 62-69. DOI: 10.1016/j.jijepes.2012.02.006

[22] Daly, P. A.; Morrison, J. Understanding the potential benefits of distributed generation on power delivery systems. // Rural Electri Power Conference. (2001), pp. 211-213. DOI: 10.1109/repcon.2001.949510

[23] Chiradeja, P.; Ramakumar, R. An approach to quantify the technical benefits of distributed generation. // IEEE Trans Energy Conversion. 19, 4(2004), pp. 764-773. DOl: 10.1109/TEC.2004.827704

[24] Balaraman, S.; Kamaraj, N. Congestion Management in Deregulated Power System Using Real Coded Genetic Algorithm. // Int. J .Electr. Power Syst. 2, 11(2010), pp. 6681-6690.

[25] Celli, G.; Ghaini, E.; Mocci, S.; Pilo, F. A multi objective evolutionary algorithm for the sizing and sitting of distributed generation. // IEEE Transactions on Power Syst. 20, 2(2005), pp. 750-757. DOI: 10.1109/TPWRS.2005.846219

[26] Swagatam Das; Arijit Biswas; Sambarta Dasgupta; Ajith Abraham. Bacterial Foraging Optimization Algorithm: Theoretical Foundations, Analysis, and Applications. // Studies in Computational Intelligence, Springer Berlin. 203, (2009), pp. 23-55. DOI: 10.1007/978-3-642-01085-9_2

[27] Xin-She Yang. Harmony Search as a Metaheuristic Algorithm. // Studies in Computational Intelligence, Springer Berlin. 191, (2009), pp. 1-14. DOI: 10.1007/978-3642-00185-7_1

[28] Chang, G. W.; Chu, S. Y.; Wang, H. L. An Improved Backward/Forward Sweep Load Flow Algorithm for Radial Distribution Systems. // IEEE Transactions on Power Syst. 22, 2(2007), pp. 882-884. DOI: 10.1109/TPWRS.2007.894848

[29] Tomoiagă, B.; Chindriş, M.; Sumper, A.; Sudria-Andreu, A.; Villafafila-Robles, R. Pareto Optimal Reconfiguration of Power Distribution Systems Using a Genetic Algorithm Based on NSGA-II. // Energies. 6, (2013), pp. 1439-1455. DOI: 10.3390/en6031439

[30] Kalyanmoy Deb, Amrit Pratap, Sameer Agarwal, T. Meyarivan. A Fast and Elitist Multiobjective Genetic Algorithm: NSGA-II. // IEEE transactions on evolutionary computation. 6, 2(2002). DOI: 10.1109/4235.996017

[31] Rashedi, E.; Nezamabadi-pour, H.; Saryazdi, S. GSA: A Gravitational Search Algorithm. // Information sciences. 179, 13(2009), pp. 2232-2248. DOI: 10.1016/j.ins.2009.03.004

[32] Kalyanmoy Deb. Multi Objective Optimization Using Evolutionary Algorithms. John Wiley \& Sons, Inc., New York, NY, USA, 2001.

\section{Authors' addresses}

Sankaramoorthy Muthubalaji, Associate Professor

Lathamathavan Engineering College

Alagarkovil, Madurai, Tamilnadu,

India, 625301

E-mail: muthusa15@gmail.com

Veluchamy Malathi, Professor

Anna University, Regional Office Madurai,

Madurai, Tamilnadu,

India, 625007

E-mail:vmeee@autmdu.ac.in 